\title{
Habitat Selection of American Woodcock and its Implications for Habitat Management Where Young Forests are Rare
}

\author{
ROGER J. MASSE, ${ }^{1,2}$ University of Rhode Island, Department of Natural Resources Science, 102 Coastal Institute in
} Kingston, Kingston, RI 02881, USA

BRIAN C. TEFFT, ${ }^{3}$ Rhode Island Department of Environmental Management, Division of Fish and Wildlife, 277 Great Neck Road, West Kingston, RI 02892, USA

BILL BUFFUM, University of Rhode Island, Department of Natural Resources Science, 102 Coastal Institute in Kingston, Kingston, RI 02881, USA

SCOTT R. MCWILLIAMS, University of Rhode Island, Department of Natural Resources Science, 102 Coastal Institute in Kingston, Kingston, RI 02881, USA

\begin{abstract}
American woodcock (Scolopax minor; hereafter woodcock) habitat use or selection has been studied extensively since the mid-1960s; most such studies, however, have taken place when and where young forest habitat selected by woodcock was relatively common. Woodcock population declines have been mostly attributed to loss of young forest vegetation types throughout the species' range. Thus, understanding woodcock habitat selection and the benefits of habitat management in areas where young forests are rare is important in conserving woodcock and other wildlife that uses young forest. We conducted studies of male radio-tagged woodcock in Rhode Island, USA, when and where the extent of upland young forests in non-coastal areas comprised only $1.4 \%$ of the land area and was decreasing by $\geq 1.5 \%$ per year. We determined habitat selection of woodcock, then used the derived resource selection function to assess potential benefits of certain forest management scenarios for male woodcock and non-target birds. Landscapes comprising deciduous wetland forests, wetland young forests with nearby agricultural openings, or patches of upland young forest received relatively high use by woodcock. After integrating habitat management scenarios into GIS, our derived resource selection function suggested that creating fewer, larger patches of upland young forest and herbaceous forest openings may be less beneficial than creating more smaller patches. Openings with early-successional forest were an important component of woodcock habitat because they provided safe nighttime roost sites where mammalian predators were less active. These openings also provided habitat for a more diverse bird assemblage than unmanaged forests. Active habitat management is required to conserve woodcock populations in many landscapes, and managers should highlight the benefits of woodcock habitat management for non-target wildlife.
\end{abstract}

Proceedings of the American Woodcock Symposium 11: 168-177

KEY WORDS: American woodcock, habitat selection, habitat management, resource selection function, predation risk, young forest, songbirds, umbrella species

The American woodcock (Scolopax minor; hereafter woodcock) is a popular game bird in eastern and central regions of the United States and eastern Canada. Hunters spent $\sim 399,700$ days afield and killed $\sim 200,200$ woodcock during

1 email: masserj@cobleskill.edu

2 current affiliation: State University of New York at Cobleskill, Fisheries, Wildlife, and Environmental Science Department,

Cobleskill, NY 12043, USA

3 retired 
the 2015-2016 season (Seamans and Rau 2016). Woodcock populations throughout the species range have declined since the late 1960s, and this does not appear to be related to hunting mortality (McAuley et al. 2005, Seamans and Rau 2016). Given that woodcock hunting mortality under current regulations is likely compensatory in nature, population declines are likely caused by habitat loss and reduced habitat quality (Sauer and Bortner 1991, Dessecker and McAuley 2001, McAuley et al. 2005).

Woodcock habitat use and selection has been studied extensively since the mid 1960s. On breeding grounds, and depending on activity and time of day, woodcock generally use a variety of early successional cover types, including herb-dominated forest openings, abandoned hayfields, recent clearcuts, and regenerating stands of young forest (Sheldon 1967, Wishart and Bider 1976, Gutzwiller et al. 1983, McAuley et al. 1996, Dessecker and McAuley 2001). Forest openings provide breeding sites (i.e., singing grounds) during springtime crepuscular periods and roosting sites during summer nights, whereas dense stands of young forest, generally $<30$ years old, provide nesting sites for females and daytime feeding sites for all age-sex classes (Kelley et al. 2008). Woodcock routinely commute on a given day between dense stands of young forest and more sparsely vegetated forest openings at dusk and dawn (Sheldon 1961, Owen and Morgan 1975, Masse et al. 2013). As a result, they spend most of their time during the breeding season in daytime feeding coverts, and these dense vegetation types are important for providing access to food and protection from diurnal predators (Keppie and Whiting 1994, Dessecker and McAuley 2001).

Most studies of woodcock habitat use during the breeding season occurred in earlier times (e.g., 1960s-1990s) or in areas (e.g., Maine, central Massachusetts, and Pennsylvania, USA; Quebec, Canada) when and where young forests were relatively common (e.g., Sheldon 1967, Wishart and Bider 1976, Hudgins et al. 1985, McAuley et al. 1996). During the 1950s-1990s, the extent of young forest declined across the northeastern and most of the north-central United States, but seedling-sapling timberland still comprised roughly $15-30 \%$ of forest cover towards the end of this period (Trani et al. 2001). However, the extent of young forest has continued to decline in most areas, and this vegetation type is rare in some regions of the woodcock breeding range. In Rhode Island, USA, shrubland or young forest vegetation types comprised only $3.3 \%$ of the land area during 2008 (Buffum et al. 2011). Importantly, these vegetation types covered only $1.4 \%$ of non-coastal uplands, sites where woodcock habitat management is most feasible, and their extent was decreasing by $\geq 1.5 \%$ per year (Buffum et al. 2011).

Because young forests have become less common on many landscapes, it is important to understand woodcock habitat use and the benefits of woodcock habitat man- agement under current conditions. This is true for managers in areas where young forest initiatives are planned or occurring; increasing the extent of these young forest vegetation types can help conserve woodcock and other wildlife. Herein we describe key findings from recent woodcock studies that we conducted in Rhode Island, and discuss their implications for habitat management. Our specific objectives were to: 1) illustrate the use of a resource selection function we developed for demonstrating responses of woodcock to different habitat management scenarios in areas where young forest is rare, and 2) highlight specific benefits of woodcock habitat management practices for woodcock and non-target birds.

\section{Study Area}

We conducted our studies at Arcadia, Big River, and Great Swamp Wildlife Management Areas (WMAs) in Kent and Washington counties, Rhode Island. Arcadia WMA was the largest (ca. 6,200 ha) followed by Big River (ca. 3,300 ha) and Great Swamp WMAs (ca. 1,500 ha). All 3 WMAs were forest-dominated, but relative amounts of dominant forest cover types differed among sites. Upland forest (coniferous, deciduous, and mixed) was co-dominant at Arcadia WMA, whereas coniferous upland forest was dominant at Big River WMA and wetland forest was dominant at Great Swamp WMA. Eastern white pine (Pinus strobus) comprised the majority of coniferous upland forests; various oaks (Quercus spp.), hickories (Carya spp.), and red maple (Acer rubrum) dominated deciduous upland forests; and red maple swamps were the most abundant wetland forest type (Enser and Lundgren 2006).

From 1995-2006, the Rhode Island Department of Environmental Management began creating scattered patches (2-5 ha each) of young forest at each WMA to help conserve woodcock and other young forest wildlife. Sections of older, secondary forest were generally clearcut, resulting in young forest patches typically dominated by coppice growth. More consistent and concentrated young forest management began at Great Swamp WMA during 2007, and that site was designated a Woodcock Habitat Demonstration Area in 2008 (Buffum et al., this volume). Young forest was rare at Arcadia and Big River WMAs (1-2\% of total area), but more common at Great Swamp WMA (15\%) given more frequent clearcutting at that site. Abandoned meadows and agricultural fields were also rare and widely scattered at each site.

\section{Methods}

\section{WOODCOCK RESOURCE SELECTION}

During April-May, 2011-2012, we captured 92 male woodcock on singing grounds using mist-nets and attached a Model A5400 transmitter (Advanced Telemetry Systems, Isanti, MN) to each bird following McAuley et al. (1993). 
We released all woodcock immediately after marking. Approximately 1 week after release, we tracked tagged woodcock via homing up to 4 times per week between 23 May-25 August and marked locations of tagged woodcock once per day (0600-1900 EST) using a Garmin eTrex GPS unit (Garmin Ltd., Canton of Schaffhausen, Switzerland). We included in our analyses 52 individuals with $>25$ locations throughout the summer monitoring period: 27 males during 2011 and 25 males during 2012.

We used kernel density methods (Worton 1989) to determine the summer home range ( $95 \%$ contour) and core-use area (50\% contour) of each bird. We estimated available and used habitat (design I study, sampling protocol A; Manly et al. 2002) at each management area by creating a single composite home range for all tagged woodcock and placing a minimum convex polygon (Mohr 1947) around this, and creating a single composite core-use area for all tagged woodcock, respectively (Masse et al. 2014). We used ArcGIS 10.1 (Environmental Systems Research Institute 2012) to clip areas of available and used habitat by forest boundaries and converted these areas into raster grids (10 $\mathrm{m}^{2}$ pixels). As described in Masse et al. (2014), we generated raster grids for elevation $(\mathrm{m})$, slope (\%), forest cover type, and distance $(\mathrm{m})$ to nearest stream, agricultural opening, upland young forest, and moist soil. We randomly selected $10 \%$ of available $(n=40,090)$ and used $(n=$ 3,047 ) pixels and extracted raster grid values from these.

We used logistic regression to estimate coefficients for the exponential resource selection function (RSF; $[w(x)$ $\left.=\exp \left(\beta_{1 x 1}+\ldots+\beta_{p x p}\right)\right]$; Manly et al. 2002) based on available and used habitat (Johnson et al. 2006). We ranked 15 candidate models using Akaike's Information Criterion (Anderson et al. 2000) and used the best-supported model to map (Raster Calculator; ArcGIS 10.1) relative probability of use by male woodcock across a 40o-ha case study area at Arcadia WMA (see Masse et al. 2014). We defined categories of relative probability of use (low $\leq 0.2446$; low-moderate $=0.2447-0.3355$; moderate $=0.3356-0.5802$; moderate-high $=0.5803^{-1.2381}$; and high $\geq 1.2382$ ) using geometrical interval classification (ArcGIS 10.1) and assessed the proportionality of our RSF to true probability of use following Johnson et al. (2006). We retained coefficients for upland and wetland forest cover types in our best-supported RSF model regardless of statistical significance because these forest types have been shown in previous studies to be used differentially for daytime coverts (Sheldon 1967, Keppie and Whiting 1994), and because retaining these cover types during modeling of hypothetical management scenarios facilitated illustrating relative differences in probability of use by woodcock across all forest cover types in the case study area. We then simulated 3 hypothetical forest management scenarios on the study area and observed how relative probability of use by woodcock changed. Scenario 1 involved creating 7 patches of young forest (2-10 ha each) and 3 herb-dominated forest openings (2-6 ha each) on 10\% (i.e., 40 ha) of the case study area (Masse et al. 2014). We compared this Scenario 1 to 2 other scenarios not previously considered in Masse et al. (2014). For Scenario 2, we simulated the same level of management, but in fewer, larger patches: 2 patches of young forest (ca. 15 ha each) and 1 10-ha herbaceous forest opening. Scenario 3 involved simulating a higher level of management on the case study area (i.e., 60 ha or $15 \%$ ) by creating 10 patches of young forest (2-10 ha each) and 5 herbaceous forest openings (2-6 ha each).

\section{WHY WOODCOCK COMMUTE}

From 1 July - 20 August 2011 - 2012, we simultaneously monitored nighttime (2030 - 0240 EST) locations for a subset of our marked woodcock. Because we were interested in determining factors that influenced woodcock commuting behavior between diurnal coverts and nocturnal roosts, we only included individuals that we detected moving between these sites. We acknowledge that some individuals may not move between diurnal coverts and nocturnal roosts, and that areas these individuals select may be particularly important. However, we did not know if individuals never moved between sites or simply did not move between sites during nights we monitored. Thus, including only the woodcock we were certain had moved provided the strongest test of the commuting hypotheses. We flushed each woodcock once from its nocturnal roost, and once from its diurnal covert on the following day, to mark exact sites where woodcock were located. After flushing, we immediately dug $5900-\mathrm{cm}^{3}$ soil pits to $10-\mathrm{cm}$ deep around each flush site (Masse et al. 2013). We sealed soil pit contents from nocturnal roosts in plastic bags overnight and collected soil macroinvertebrates via hand sorting the following day, whereas we immediately collected soil macroinvertebrates from soil pits dug at diurnal coverts. We also monitored mammalian predator activity at nocturnal roosts and diurnal coverts during 2011 and 2012 using baited track stations (Linhart and Knowlton 1975) and camera traps (Gompper et al. 2006), respectively (Masse et al. 2013). For each tagged woodcock's locations, we simultaneously monitored sites for evidence of mammalian predator activity for a 10-day (2011) or 14-day period (2012).

We quantified food availability at nocturnal roosts and diurnal coverts for 38 woodcock (2011: $n=17 ; 2012: n=21$ ). We calculated earthworm (Haplotaxida) mass (g), density $\left(\right.$ no. $\left./ \mathrm{m}^{2}\right)$ of potential prey, and species richness and diversity (Jost 2006) of potential prey at nocturnal roosts and diurnal coverts, and compared these using paired $t$-tests or Wilcoxon signed-rank tests (Ott and Longnecker 2010). To maintain our paired design and promote independence of observations, we quantified predator activity at nocturnal roosts and diurnal coverts for 11 woodcock during 
2011 and 12 woodcock during 2012 (see Masse et al. 2013). During 2011, we counted the number of nights (out of 10) that a mammalian predator visited a woodcock's nocturnal roost or diurnal covert and compared these counts using log-linear regression (Agresti 2007, Pedan 2011) with woodcock frequency as a random effect. During 2012, we used paired $t$-tests to compare the number of days until any predator (mammalian or avian) visited a woodcock's nocturnal roost or diurnal covert.

\section{BENEFITS OF WOODCOCK HABITAT MANAGEMENT FOR NON-TARGET BIRDS}

Each spring, we marked locations of singing grounds using a Garmin eTrex GPS unit and quantified the relative abundance and diversity of non-target birds associated with these sites using standard (i.e., 10-min, 50-m radius) point count surveys (Ralph et al. 1993) from 27 May - 2 July. We limited point counts to woodcock singing grounds-as opposed to randomly selected patches of young forestbecause singing grounds are critical components of woodcock habitat (Dessecker and McAuley 2001) and we were certain woodcock were using these exact sites. Thus, this provided a sound study design for assessing the potential of woodcock to serve as an umbrella species. During 2011, we surveyed a random subset of 9 singing grounds at Arcadia and Great Swamp WMAs that were $\geq 200 \mathrm{~m}$ from other singing grounds, and during 2012-2013 we surveyed a random subset of 10 singing grounds at each of the 3 WMAs (Masse et al. 2015). We also generated a random sample of 10 locations in unmanaged forest (i.e., 60-100 yearold second-growth) at each WMA and conducted identical point counts at these sites each year. We counted the total number of birds and calculated bird diversity (Jost 2006) at each singing ground and random forest site, and compared these using a linear mixed model (see Masse et al. 2015). We also calculated relative abundances for the 3 most common species at each type of site to highlight differences in the composition of bird assemblages.

\section{Results}

Our highest-ranked RSF indicated that probability of use by male woodcock increased in deciduous wetland forest $(\beta=0.68390, \mathrm{SE}=0.06688, z=10.225, P<0.01)$, wetland young forest $(\beta=0.39340, \mathrm{SE}=0.09719, z=4.048, P<$ $0.01)$, and mixed wetland forest $(\beta=0.19930, \mathrm{SE}=0.09273$, $z=2.149, P=0.03$ ), and marginally so in deciduous upland forest $(\beta=0.09060, \mathrm{SE}=0.05612, z=1.614, P=0.11)$, compared to mixed upland forest [(reference cover type; see Masse et al. (2014) for a more complete description of the RSF]. Increased elevation $(\beta=0.00210, S E=0.00076$, $z=2.781, P<0.01$ ) led to increased probability of use by woodcock. Probability of use by woodcock decreased in coniferous upland forest $(\beta=-0.31110, \mathrm{SE}=0.06277, z=$ $-4.956, P<0.01)$ and upland young forest $(\beta=-0.22690$, SE $=0.13770, z=-1.648, P=0.10)$, and was not influenced by coniferous wetland forest $(\beta=-0.02730, \mathrm{SE}=0.16460, z=$ $-0.166, P=0.87)$ compared to mixed upland forest. In addition, probability of use by woodcock decreased on higher slopes $(\beta=-0.01870, \mathrm{SE}=0.00354, z=-5.295, P<0.01)$ and at greater distances to the nearest agricultural opening $(\beta=$ -0.00162, $\mathrm{SE}=0.00008, z=-20.718, P<0.01)$, moist soil $(\beta$ $=-0.00117, \mathrm{SE}=0.00024, z=-4.954, P<0.01)$, stream $(\beta$ $=-0.00080, \mathrm{SE}=0.00011, z=-7.508, P<0.01)$, and upland young forest $(\beta=-0.00025, \mathrm{SE}=0.00006, z=-4.460, P<$ o.01). Management Scenario 1 reduced the extent of low probability of use by 92 ha, whereas we observed simultaneous increases in the extents of low-moderate $(+26 \mathrm{ha})$, moderate $(+38 \mathrm{ha})$, and moderate-high $(+16 \mathrm{ha})$ probabil-

Table 1. Forest area (ha) in each category of relative probability of use [P(use)] by male American woodcock before and after implementation of 3 possible habitat management scenarios simulated using a Resource Selection Function developed for woodcock (Masse et al. 2014) in Rhode Island, USA. Change in forest area $(\Delta)$ illustrates how probability of use changed in response to each forest management scenario (i.e., $\Delta=$ after - before). Management Scenario 1 involved managing 40 ha ( $10 \%$ of study area in southwestern Rhode Island) by creating 7 patches of young forest ( $2-10$ ha each) and 3 herbaceous forest openings ( $2-6$ ha each). Scenario 2 involved the same amount of management (i.e., 40 ha), but in fewer, larger patches of young forest $(n=2 ; 15$ ha each) and 1 herbaceous forest opening ( 10 ha). Scenario 3 involved managing 60 ha ( $15 \%$ of case study area) by creating 10 patches of young forest $(2-10$ ha each) and 5 herbaceous forest openings (2-6 ha each).

\begin{tabular}{|c|c|c|c|c|c|c|c|c|c|}
\hline \multirow[b]{2}{*}{$\mathbf{P}($ use $)$} & \multicolumn{3}{|c|}{ Management Scenario 1} & \multicolumn{3}{|c|}{ Management Scenario 2} & \multicolumn{3}{|c|}{ Management Scenario 3} \\
\hline & Before & After & $\Delta$ & Before & After & $\Delta$ & Before & After & $\Delta$ \\
\hline Low & 210 & 118 & -92 & 210 & 196 & -14 & 210 & 120 & -90 \\
\hline Low-moderate & 77 & 103 & 26 & 77 & 78 & 1 & 77 & 106 & 29 \\
\hline Moderate & 77 & 115 & 38 & 77 & 81 & 4 & 77 & 111 & 34 \\
\hline Moderate-high & 22 & 38 & 16 & 22 & 26 & 4 & 22 & 37 & 15 \\
\hline High & 3 & 5 & 2 & 3 & 4 & 1 & 3 & 5 & 2 \\
\hline
\end{tabular}




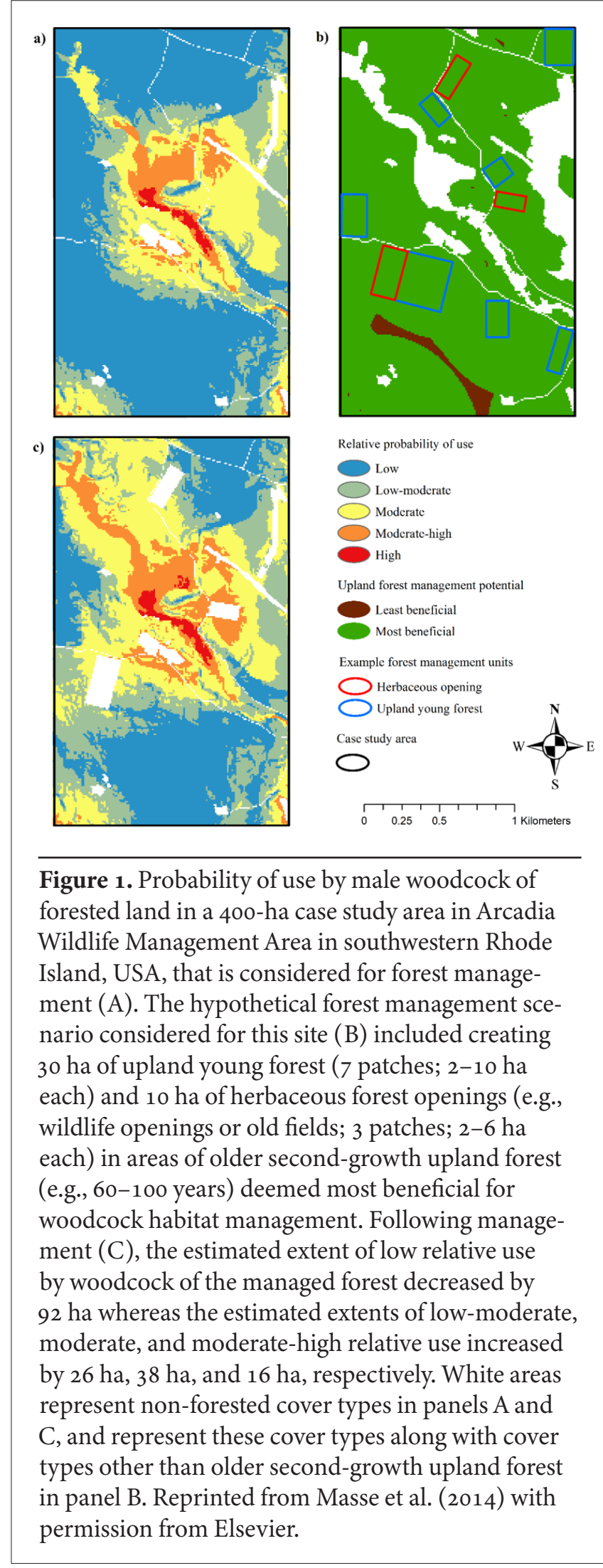

ities of use (Fig. 1). Scenario 2 reduced the extent of low probability of use from 210 ha to $196 \mathrm{ha}$. All other catego-
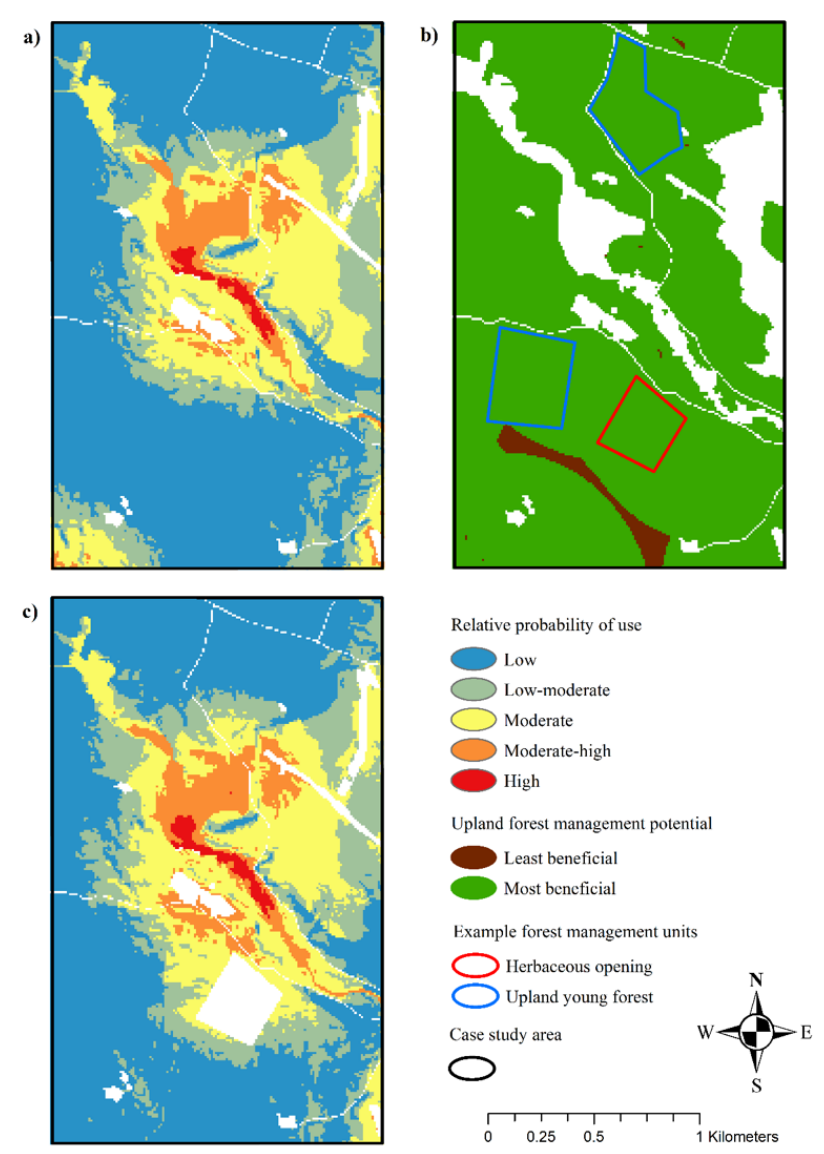

Figure 2. Probability of use by male woodcock of forested land in a 400-ha case study area in Arcadia Wildlife Management Area in southwestern Rhode Island, USA, that is considered for forest management (A). The hypothetical forest management scenario considered for this site (B) included creating 30 ha of upland young forest ( 2 patches; 15 ha each) and one 10-ha herbaceous forest opening (e.g., wildlife opening or old field) in areas of older second-growth upland forest (e.g., 60-100 years) deemed most beneficial for woodcock habitat management. Following management $(\mathrm{C})$, the estimated extent of low relative use by woodcock of the managed forest decreased by 14 ha. The estimated extents of low-moderate, moderate, and moderate-high relative use increased by $\leq 4$ ha. White areas represent non-forested cover types in panels $\mathrm{A}$ and $\mathrm{C}$, and represent these cover types along with cover types other than older second-growth upland forest in panel B.

ries of use increased by $\leq 4$ ha (Fig. 2; Table 1). In contrast, Scenario 3 reduced the area of low probability of use from 210 ha to 120 ha and increased the areas of low-moderate (+29 ha), moderate (+34 ha), and moderate-high (+15 ha) probabilities of use (Fig. 3 ). 
Average earthworm density (no. $/ \mathrm{m}^{2}$ ) was consistently greater at male woodcock diurnal coverts $(2011=30.59$; $2012=15.66)$ than nocturnal roosts $\left(2011=9.93, t_{16}=2.14\right.$, $\left.P=0.02 ; 2012=4.23, t_{20}=2.52, P=0.01\right)$. Likewise, the average difference in earthworm fresh mass between diurnal coverts and nocturnal roosts was approximately 10 grams during $2011\left(t_{16}=2.10, P=0.03\right)$ and $2012\left(t_{20}=\right.$ $3.25, P<0.01)$. The average difference in earthworm dry mass between sites was approximately $3 \mathrm{~g}$ during 2011 $\left(t_{16}=2.12, P=0.03\right)$ and 2 grams during $2012\left(t_{20}=3.39\right.$, $P<0.01)$. The combined density of potential woodcock prey was similar at diurnal covers and nocturnal roosts during $2011\left(t_{16}=1.14, P=0.27\right)$ and $2012(\mathrm{~V}=102, P=$ $0.66)$, whereas richness $\left(t_{16}=2.85, P=0.01\right)$ and diversity $\left(t_{16}=2.30, P=0.04\right)$ of woodcock prey tended to be higher at diurnal coverts during 2011. During 2012, richness ( $t_{20}$ $=1.06, P=0.30)$ and diversity $\left(t_{20}=0.54, P=0.59\right)$ of woodcock prey were similar between sites (see Fig. $1 \mathrm{~B}-\mathrm{C}$ in Masse et al. 2013). Mammalian predators visited track stations at nocturnal roosts less often than diurnal coverts for 8 of 11 marked woodcock during $2011\left(\mathrm{~F}_{1}, 10=8.11, P\right.$ $=0.02$ ), and the number of days until initial predator visit was longer at nocturnal roosts than diurnal coverts for 9 of 12 woodcock during $2012\left(t_{11}=2.02, P=0.03\right)$.

On average, the number and diversity of birds associated with singing grounds was $\geq 1.5$ times greater than that of unmanaged forest sites at each of the WMAs (Fig. 4). At each WMA, young forest species such as cedar waxwing (Bombycilla cedrorum), gray catbird (Dumetella carolinensis), common yellowthroat (Geothlypis trichas), and prairie warbler (Setophaga discolor) were more common at singing grounds (Fig. 1 in Masse et al. 2015). In contrast, forest generalists (e.g., red-eyed vireo [Vireo olivaceus]) or more mature forest species (e.g., ovenbird [Seiurus aurocapilla]) were most common at unmanaged forest sites during our breeding season surveys, but such species readily utilize patches of young forest during the post-fledging period (Chandler et al. 2012).

\section{Discussion}

We found that in areas where upland young forests are rare, male woodcock tend to use forest cover types other than upland young forests for daytime coverts. Specifically, deciduous wetland forests were favored, followed by wetland young forests and mixed wetland forests. Coniferous upland forests exerted the strongest negative effect on probability of use by woodcock, whereas we detected no significant effect of deciduous upland forest, upland young forest, and coniferous wetland forest on probability of use by woodcock. Although young upland forests typically are regarded as an important component of woodcock habitat (Keppie and Whiting 1994), these areas were uncommon at our study sites and tended to be less frequently used by male woodcock compared to some other forest types.
We conclude that in areas where preferred young upland forests are rare, male woodcock select among the best remaining available vegetation types (Sepik et al. 1989),
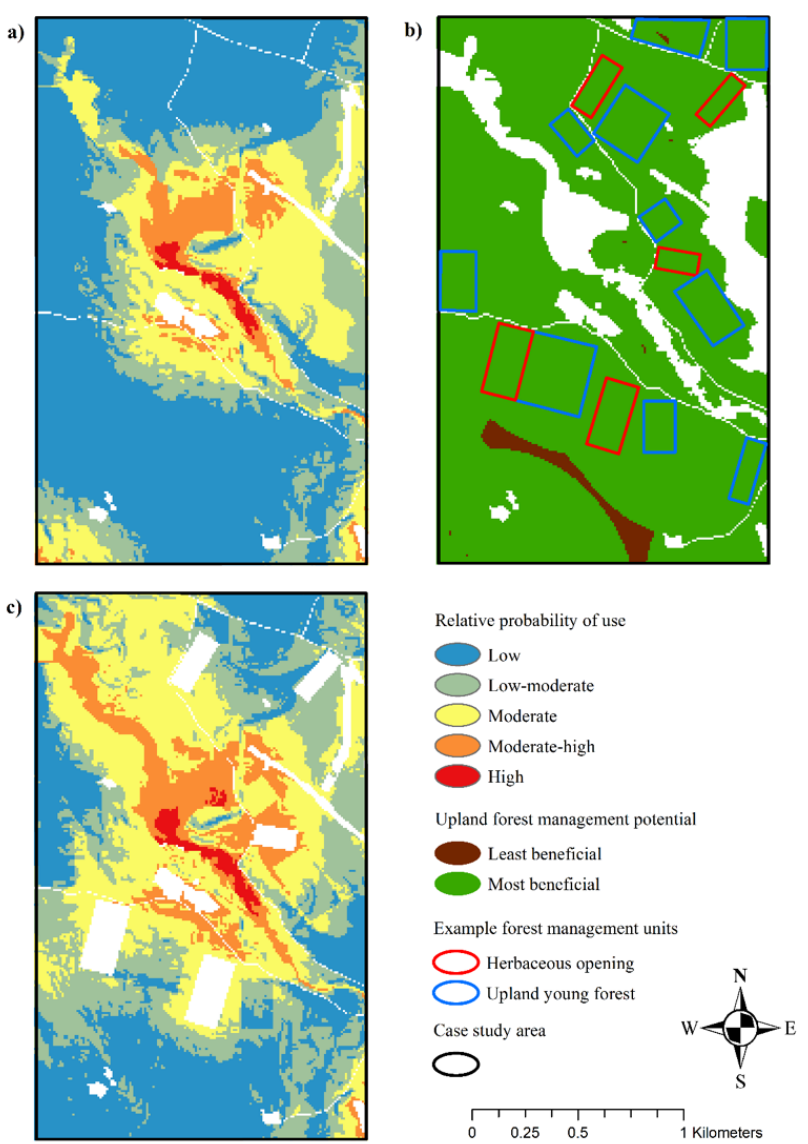

Figure 3. Probability of use by male woodcock of forested land in a 400-ha case study area in Arcadia Wildlife Management Area in southwestern Rhode Island, USA, that is considered for forest management (A). The hypothetical forest management scenario considered for this site (B) included creating about 40 ha of upland young forest (10 patches; 2-10 ha each) and 20 ha of herbaceous forest openings (e.g., wildlife openings or old fields; 5 patches; 2-6 ha each) in areas of older second-growth upland forest (e.g., 60-100 years) deemed most beneficial for woodcock habitat management. Following management $(\mathrm{C})$, the estimated extent of low relative use by woodcock of the managed forest decreased by 90 ha whereas the estimated extents of low-moderate, moderate, and moderate-high relative use increased by 29 ha, 34 ha, and 15 ha, respectively. White areas represent non-forested cover types in panels $A$ and $\mathrm{C}$, and represent these cover types along with cover types other than older second-growth upland forest in panel $B$. 
which in our study area was wetland forests with relatively dense understory vegetation (Masse et al. 2014). However, because we only investigated male woodcock, and we did not investigate demographic parameters such as survival or reproduction, we are unable to speculate on the consequences of this habitat use for woodcock populations in southern New England.

In Rhode Island, higher shrub and sapling density, and shorter and smaller-diameter trees, characterized deciduous wetland forests and wetland young forests favored by male woodcock (Masse et al. 2014). These patterns are similar to structural characteristics of woodcock diurnal coverts described in other parts of the breeding range (Rabe 1977, Hudgins et al. 1985, Straw et al. 1986, Keppie and Whiting 1994). Consequently, these wetland forest types may provide woodcock with similar protective cover from diurnal predators in areas where upland young forests are rare. Indeed, older forests (e.g., >30 years) may represent an important component of woodcock habitat if

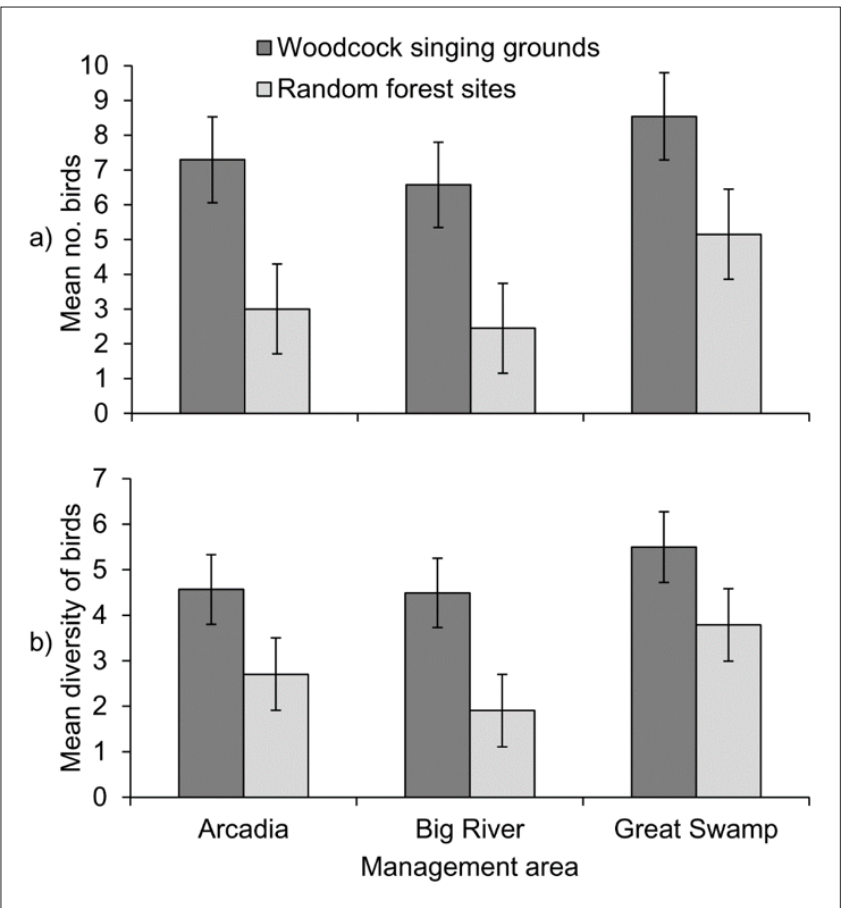

Figure 4. Mean number of birds (A) and diversity of birds (B) per 50-m-radius point count location at woodcock singing grounds and nearby random forest sites based on 10-minute point count surveys conducted from 27 May-2 July 2011-2013 at Arcadia and Great Swamp Wildlife Management Areas, and 2012-2013 at Big River Wildlife Management Area, in Kent and Washington counties, Rhode Island, USA. Whiskers represent $95 \%$ CIs. Reprinted from Masse et al. (2015) with permission from John Wiley and Sons. shrub and sapling densities are sufficiently high (Williamson 2010). Areas with moist soils also help to ensure more consistent access to earthworms (Dessecker and McAuley 2001), and so deciduous wetland forests and young wetland forests in Rhode Island were likely favored by woodcock because these areas provided adequate food and cover (Masse et al. 2014).

In addition to quantifying how landscape covariates influenced probability of use by male woodcock, our RSF was useful in predicting how probability of use might change following forest management. This is a potentially important application of our RSF, and of others developed in the future, because extensive woodcock habitat management will be required to stabilize and ultimately increase woodcock populations (McAuley et al. 2005, Kelley et al. 2008). For example, Williamson (2008) suggested maintaining young forest on about $27 \%$ of Rhode Island's land area to increase young forest bird populations to levels observed during 1970. In contrast, Dettmers and Rosenberg (2000) suggested a more likely goal of managing young forest on $10 \%$ of the land in southern New England to conserve these species.

Across our 400 -ha study area, managing 40 ha $(10 \%)$ as a series of upland young forest patches $(n=7 ; 2-10$ ha each) and herbaceous forest openings ( $n=3 ; 2-6$ ha each) caused the largest change in probability of use by male woodcock (Table 1; Fig. 1). Managing larger patches (e.g., $\geq 10$ ha each) is suggested for conserving some young forest wildlife (e.g., New England cottontail [Sylvilagus transitionalis]; Arbuthnot 2008), but this strategy produced minimal change to probability of use by woodcock on our study area (Fig. 2). Young forest birds do not exhibit area-sensitivity with respect to survival and productivity (Rodewald and Vitz 2005, Lehnen and Rodewald 2009), these species are therefore adapted to exploit smaller, more localized patches of habitat. Interestingly, our more intensive management Scenario 3 (i.e., 6o ha or $15 \%$ ) yielded nearly identical changes to probability of use as our less intensive management Scenario 1 (Table 1, Figs. 1 and 3). We acknowledge that altering the size, shape, and/or location of managed patches may have produced different results given the landscape and distance parameters incorporated into our RSF. In this regard, there are endless combinations of patch size, shape, and conFiguration that could have been simulated. The purpose of our RSF simulation was to illustrate that these models can be used to compare potential outcomes of competing management scenarios and work towards selecting a management option that is relatively more beneficial in terms of increasing the probability of use by a target species such as woodcock. When available, RSFs can help habitat managers visualize probability of use by target wildlife to certain management practices or scenarios. In doing so, managers 
can build support for implementing strategies that may produce the greatest probability of use.

Our RSF indicates that converting patches of older coniferous upland forest to young forest would benefit woodcock because coniferous upland forests negatively affected relative probability of use. However, coniferous uplands may be important for woodcock during drought years (Sepik et al. 1983), and therefore some of these areas should remain intact. Male woodcock were more likely to use areas closer to upland young forest patches, and closer to agricultural openings. This explains why creating more, smaller patches of young forest and herbaceous forest openings on our study area elicited a stronger positive change to relative probability of use than creating fewer, larger patches. We emphasize that our RSF is applicable in helping to predict the potential consequences of woodcock habitat management in southern New England or similar regions or landscapes where young forests are rare and forested wetlands are a component of the landscape.

Male woodcock prefer forests closer to herbaceous forest openings because these openings serve as safe nighttime roost sites during summer (Masse et al. 2013). Woodcock commuting behavior has long been known (Sheldon 1961), but specific benefits of moving between diurnal coverts and nocturnal roosts had remained undocumented. Dunford and Owen (1973) were the first to suggest that nocturnal roost sites offered safe refuge from predators, but there had been no attempts to support or refute this predation-risk hypothesis with field data. Our paired study design was unique in that we were able to assess both food availability and mammalian predation risk at the diurnal coverts and nocturnal roosts for individuals that chose to move between these different vegetation types. In Rhode Island, mammalian predators were either more abundant or more active at diurnal coverts compared to nocturnal roosts, so moving to roost fields at night provided periods of relative safety (Masse et al. 2013). We attempted to quantify avian predation risk by monitoring the fate of live rock pigeons (Columba livia) placed at diurnal coverts and nocturnal roosts, but raptors never visited these caged birds at either site (see Masse et al. 2013). This evidence suggests that avian predation risk at diurnal coverts and nocturnal roosts was similar. We simultaneously documented more preferred foods at diurnal coverts compared to nocturnal roosts, which supports earlier conclusions that woodcock generally do not move to nocturnal roost sites to exploit feeding opportunities (Krohn 1970, Wishart and Bider 1976).

Active forest management is required to conserve populations of woodcock and other young forest birds in many landscapes, but young forests and other early-successional vegetation types are often viewed unfavorably by the general public (Gobster 2001). As a result, managers of public lands may experience resistance when proposing young forest management plans aimed primarily at a single target species (e.g., Woodcock Habitat Demonstration Areas). In areas where young forests are rare, sites managed to provide components of woodcock habitat (i.e., singing grounds) simultaneously provided benefits to a greater number and diversity of non-target birds than unmanaged forest sites (Fig. 4). Young forest birds, several of which are identified as species of high continental or regional conservation priority (Dettmers and Rosenberg 2000) or species of greatest conservation need (RIDEM 2005), were more abundant at woodcock singing grounds and largely absent at unmanaged forest sites (Masse et al. 2015). Best management practices for woodcock generally call for creating mosaics of $\geq 2$ ha clearcut patches or 30 - $\mathrm{m}$ strips on target landscapes (McAuley et al. 1996, Williamson 2010). Our findings suggest that many non-target birds readily use small patches of young forest or herb-dominated forest openings managed to provide components of woodcock habitat. Use of small clearcuts (e.g., 1-4 ha) by young forest birds has been documented elsewhere (Schlossberg and King 2007), but our study was unique in that we conducted bird surveys in areas actively being managed for and used by woodcock. Woodcock may serve as an umbrella species for young forest bird assemblages (Masse et al. 2015), although additional studies are needed that document whether woodcock habitat management leads to increased reproduction and/or survival of non-target songbird species. This additional demographic information on songbirds could be used to increase public awareness about the many benefits of young forest management, and to convince private landowners that targeted and well-planned forest clearcutting is not necessarily at odds with broader conservation goals focused on songbirds and game species such as woodcock.

\section{Acknowledgments}

We thank the many volunteers who assisted with woodcock captures. We also thank T. Heywood, S. Camillieri, J. Veale, J. Travers, A. Hunt, A. Padula, W. Shean, L. Barnard, D. Duffin, and D. McAuley for their valuable help in the field, and A. Smith and L. Gonzalez for statistical advice. We also thank D. Andersen and two anonymous reviewers for constructive criticisms on an earlier draft of this manuscript. Funding for this project was provided by the Rhode Island Agricultural Experiment Station, the U.S. Department of Agriculture McIntyre-Stennis (MS-975) and Hatch (H-333) programs, the Rhode Island Department of Environmental Management via USFWS Federal Aid to Wildlife Investigations Project W-23R, and the Department of Natural Resources Science at University of Rhode Island. This is contribution number 5466 of the Rhode Island Agricultural Experiment Station. 


\section{Literature Cited}

Agresti, A. 2007. An introduction to categorical data analysis, second edition. John Wiley and Sons, Hoboken, New Jersey, USA.

Anderson, D.R., K.P. Burnham, and W.L. Thompson. 200o. Null hypothesis testing: problems, prevalence, and an alternative. Journal of Wildlife Management 64:912-923.

Arbuthnot, M. 2008. A landowner's guide to New England cottontail habitat management. Environmental Defense Fund. US Fish and Wildlife Publications, 372.

Buffum, B., B.C. Tefft, R.J. Masse, and S.R. McWilliams. 2019. Mobilizing private landowners to create American woodcock habitat: lessons learned in Rhode Island. Pages 85-90 in D.G. Krementz, D.E. Andersen, and T. R. Cooper, Editors. Proceedings of the Eleventh American Woodcock Symposium. University of Minnesota Libraries Publishing, Minneapolis, Minnesota, USA.

Buffum, B., S.R. McWilliams, and P.V. August. 2011. A spatial analysis of forest management and its contribution to maintaining the extent of shrubland habitat in southern New England, United States. Forest Ecology and Management 262:1775-1785.

Chandler, C.C., D.I. King, and R.B. Chandler. 2012. Do mature forest birds prefer early-successional habitat during the post-fledging period? Forest Ecology and Management 264:1-9.

Dessecker, D.R., and D.G. McAuley. 2001. Importance of early successional habitat to ruffed grouse and American woodcock. Wildlife Society Bulletin 29:456-465.

Dettmers, R., and K.V. Rosenberg. 200o. Partners in Flight landbird conservation plan: physiographic area 9: southern New England, Version 1.o. Partners in Flight, Northeast Region, Ithaca, New York, USA. <http://www.partnersinflight.org/bcps/plan/ pl_09_10.pdf $>$. Accessed 6 February 2014.

Dunford, R.D., and R.B. Owen, Jr. 1973. Summer behavior of immature radio-equipped woodcock in central Maine. Journal of Wildlife Management 37:462-469.

Enser, R. W, and J.A. Lundgren. 2006. Natural communities of Rhode Island. Rhode Island Natural History Survey, Kingston, Rhode Island, USA. <http://rinhs.org/wpcontent/ uploads/2012/05/ri_nat_comms_2006.pdf $>$. Accessed 19 October 2013.

Environmental Systems Research Institute. 2012. ArcGIS Desktop Advanced Student Edition: Release 10.1. Environmental Systems Research Institute, Redlands, California, USA.

Gobster, P.H. 2001. Human dimensions of early successional landscapes in the eastern United States. Wildlife Society Bulletin 29:474-482.

Gompper, M.E., R.W. Kays, J.C. Ray, S.D. Lapoint, D.A. Bogan, and J.R. Cryan. 2006. A comparison of noninvasive techniques to survey carnivore communities in northeastern North America. Wildlife Society Bulletin 34:1142-1151.

Gutzwiller, K.J., K.R. Kinsley, G.L. Storm, W.M. Tzilkowski, and J.S. Wakeley. 1983. Relative value of vegetation structure and species composition for identifying American woodcock breeding habitat. Journal of Wildlife Management 47:535-540.

Hudgins, J.E., G.L. Storm, and J.S. Wakeley. 1985. Local movements and diurnal-habitat selection by male American woodcock in Pennsylvania. Journal of Wildlife Management 49:614-619.

Johnson, C.J., S.E. Nielsen, E.H. Merrill, T.L. McDonald, and M.S. Boyce. 2006. Resource selection functions based on use-availability data: theoretical motivation and evaluation methods. Journal of Wildlife Management 70:347-357.

Jost, L. 2006. Entropy and diversity. Oikos 113:363-375.

Kelley, J., S. Williamson, and T.R. Cooper, editors. 2008. American woodcock conservation plan: a summary of and recommendations for woodcock conservation in North America. Wildlife Management Institute. <http://timberdoodle.org/sites/default/ files/woodcockPlan_o.pdf $>$. Accessed 18 August 2017.
Keppie, D.M., and R.M. Whiting, Jr. 1994. American woodcock (Scolopax minor), in: Poole, A (Ed.), The Birds of North America. Cornell Lab of Ornithology, Ithaca, New York, USA.

Krohn, W.B. 1970. Woodcock feeding habits as related to summer field usage in central Maine. Journal of Wildlife Management 34:769-775.

Lehnen, S.E., and A.D. Rodewald. 2009. Investigating area-sensitivity in shrubland birds: responses to patch size in a forested landscape. Forest Ecology and Management 257:2308-2316.

Linhart, S.B., and F.F. Knowlton. 1975. Determining the relative abundance of coyotes by scent station lines. Wildlife Society Bulletin 3:119-124.

Manly, B.F.J., L.L. McDonald, D.L. Thomas, T.L. McDonald, and W.P. Erickson. 2002. Resource selection by animals: statistical design and analysis for field studies, second edition. Kluwer Academic Publishers, Dordrecht, Netherlands.

Masse, R.J., B.C. Tefft, J.A. Amador, and S.R. McWilliams. 2013. Why woodcock commute: testing the foraging-benefit and predation-risk hypotheses. Behavioral Ecology 24:1348-1355.

Masse, R.J., B.C. Tefft, and S.R. McWilliams. 2014. Multiscale habitat selection by a forest-dwelling shorebird, the American woodcock: implications for forest management in southern New England, USA. Forest Ecology and Management 325:37-48.

Masse, R.J., B.C. Tefft, and S.R. McWilliams. 2015. Higher bird abundance and diversity where American woodcock sing: fringe benefits of managing forests for woodcock. Journal of Wildlife Management 79:1378-1384.

McAuley, D.G., J.R. Longcore, D.A. Clugston, R.B. Allen, A. Weik, S. Williamson, J. Dunn, B. Palmer, K. Evans, W. Staats, G.F. Sepik, and W. Halteman. 2005. Effects of hunting on survival of American woodcock in the Northeast. Journal of Wildlife Management 69:1565-1577.

McAuley, D.G., J.R. Longcore, and G.F. Sepik. 1993. Techniques for research into woodcock: experiences and recommendations. Pages 5-11 in J.R. Longcore and G.F. Sepik, editors. Proceedings of the Eighth American Woodcock Symposium. U.S. Fish and Wildlife Service, Biological Report 16. Washington, D.C., USA.

McAuley, D.G., J.R. Longcore, G.F. Sepik, and G.W. Pendleton. 1996. Habitat characteristics of American woodcock nest sites on a managed area in Maine. Journal of Wildlife Management 60:138-148.

Mohr, C.O. 1947. Table of equivalent populations of North American small mammals. American Midland Naturalist 37:223-249.

Ott, R.L., and M. Longnecker. 2010. An introduction to statistical methods and data analysis, sixth edition. Brooks/Cole, Belmont, California, USA.

Owen, Jr., R. B, and J.W. Morgan. 1975. Summer behavior of adult radio-equipped woodcock in central Maine. Journal of Wildlife Management 39:179-182.

Pedan, A. 2011. Analysis of count data using the SAS system. Statistics, Data Analysis, and Data Mining. <http://www2.sas.com/ proceedings/sugi26/p247-26.pdf $>$. Accessed 18 August 2017.

Rabe, D. 1977. Structural analysis of woodcock diurnal habitat in northern Michigan. Pages 125-134 in J.R. Longcore and G.F. Sepik, editors. Proceedings of the Sixth Woodcock Symposium. U.S. Fish and Wildlife Service. Washington, D.C., USA.

Ralph, C.J., G.R. Geupel, P. Pyle, T.E. Martin, and D.F. DeSante. 1993. Handbook of field methods for monitoring landbirds. U.S. Forest Service, Pacific Southwest Research Station, General Technical Report PSW-GTR-144-www, Albany, California, USA.

RIDEM. 2005. Rhode Island's comprehensive wildlife conservation strategy. Division of Fish and Wildlife, State of Rhode Island Department of Environmental Management, Providence, Rhode Island, USA. <http://www.dem.ri.gov/programs/bnatres/fishwild/pdf/swgplan.pdf $>$. Accessed 18 August 2017.

Rodewald, A.D., and A.C. Vitz. 2005. Edge- and area-sensitivity of shrubland birds. Journal of Wildlife Management 69:681-588. 
Sauer, J.R., and J.B. Bortner. 1991. Population trends from the American woodcock singing ground survey, 1970-88. Journal of Wildlife Management 55:300-312.

Schlossberg, S., and D.I. King. 2007. Ecology and management of scrub-shrub birds in New England: a comprehensive review. Natural Resources Conservation Service, Resource Inventory and Assessment Division, Beltsville, Maryland, USA.

Seamans, M.E., and R.D. Rau. 2016. American woodcock population status, 2016. U.S. Fish and Wildlife Service, Laurel, Maryland, USA.

Sepik, G.F., D.G. McAuley, J.R. Longcore, and E.L. Derleth. 1989. Habitat requirements and management of woodcock in the Northeast: assessment of knowledge and needs. Pages 97-109 in J.C. Finley and M.C. Brittingham, editors. Timber management and its effects on wildlife: Proceedings of the 1989 Pennsylvania state forest resources issues conference. Pennsylvania State University, University Park, Pennsylvania, USA.

Sepik, G.F., R.B. Owen Jr., and T.J. Dwyer. 1983. The effect of drought on a local woodcock population. Transactions of the Northeast Fish and Wildlife Conference 40:1-8.

Sheldon, W.G. 1961. Summer crepuscular flights of American woodcock in central Massachusetts. Wilson Bulletin 73:126-139.
Sheldon, W.G. 1967. The book of the American woodcock. University of Massachusetts, Amherst, USA.

Straw Jr., J.A., J.S. Wakeley, and J.E. Hudgins. 1986. A model for management of diurnal habitat for American woodcock in Pennsylvania. Journal of Wildlife Management 50:378-383.

Trani, M.K., R.T. Brooks, T.L. Schmidt, V.A. Rudis, and C.M. Gabbard. 2001. Patterns and trends of early successional forests in the eastern United States. Wildlife Society Bulletin 29:413-424.

Williamson, S. 2008. Bird conservation region 30: New England/ mid-Atlantic coast. Pages 138-147 in Kelley, J., S. Williamson, and T.R. Cooper, editors. American woodcock conservation plan. Wildlife Management Institute.

<http://timberdoodle.org/sites/default/files/woodcockPlan_o.pdf $>$. Accessed 18 August 2017.

Williamson, S.J. 2010. American woodcock: habitat best management practices for the Northeast. U.S. Department of Agriculture, Natural Resources Conservation Service Wildlife Insight 89, Washington, D.C., USA.

Wishart R. A, and J.R. Bider. 1976. Habitat preferences of woodcock in southwestern Quebec. Journal of Wildlife Management 40:523-531.

Worton, B.J. 1989. Kernel methods for estimating the utilization distribution in home-range studies. Ecology 70:164-168. 